\title{
Study of Genetic Divergence in Tomato (Solanum lycopersicum L.)
}

\author{
Sooraj Maurya $^{1 *}$, A.K. Singh ${ }^{1}$, S.K. Singh ${ }^{2}$ and Om Prakash Kumawat ${ }^{1}$ \\ ${ }^{1}$ Department of Horticulture, ${ }^{2}$ Department of Plant Breeding and Genetics, Dr. Rajendra \\ Prasad Central Agricultural University, Pusa, Sanastipur, Bihar-848125, India \\ *Corresponding author:
}

Keywords

Divergence,

Cluster, Genotypes,

Solanum

lycopersicum $\mathrm{L}$.

Article Info

Accepted:

18 July 2019

Available Online:

20 August 2019

\section{A B S T R A C T}

Present investigation was carried out at Vegetable Research Farm, RPCAU, Pusa, Samastipur, Bihar during 2018-19 (Rabi). About thirty genotypes were evaluated for 15 growth, yield and quality characters which were grouped into six clusters. Cluster I topped in having maximum of ten genotypes followed by cluster IV and V with seven genotypes each, cluster II with four genotypes, while cluster III and VI were monotypic (one genotype each). The maximum intra cluster distance was observed in cluster IV (550.48) followed by clusters IV (490.54), cluster II (397.02) and cluster I (379.42) which were identified genetically divergent. The maximum inter cluster distance was noticed between cluster VI and III (7043.88) and lowest between cluster II and I (596.75). The genotypes of cluster VI recorded maximum mean values for number of flower per cluster, fruit per cluster and number of fruits per plant while average fruit weight and fruit yield per plant maximum values were recorded in genotypes belonging to clusters V. Among the fifteen characters studied ascorbic acid content contributed highest divergence followed by average fruit weight have a major role in improvement of fruit yield in tomato.

\section{Introduction}

Tomato (Solanum lycopersicum L.) is an important vegetable crop grown in the world belongs to the Solanaceae family and having diploid chromosome number $2 \mathrm{n}=24$. Although, it is cultivated worldwide and have high yield potential but the average yield is very low due to non-availability of improved varieties. It can be achieved by selecting the genotypes with desirable characters combinations existing in nature or by hybridization (Reddy et al., 2013). Genetic diversity plays a very important role as it helps in selecting the suitable parents for hybridization programme resulting in superior hybrids and desirable recombinants (Ruthi et al., 2011). In the present study is an attempt to obtain information on the genetic diversity in thirty genotypes of tomato and asses their utility in developing hetrotic combination for commercial purpose.

\section{Materials and Methods}

The present investigation was carried out Vegetable Research Farm, Dr. Rajendra Prasad Central Agricultural University Pusa, 
Samastipur (Bihar). Experiment was laid down in Randomized Block Design along with thirty genotypes in three replication. During 2018-19 (Rabi season) thirty days old seeding were transplanted in the field with spacing of $45 \mathrm{~cm}$ between plant to plant and $75 \mathrm{~cm}$ between row to row. Necessary inter cultural operation was carried out during cropping period for proper growth and development of the plants. Various morphological traits viz., plant height at maturity stage, primary branches per plant, number of days to $50 \%$ flowers initiation, days to $50 \%$ fruits initiation, number of flowers per cluster, number of fruits per cluster, number of locules per fruits, number of days to physiological maturity of fruits, polar diameter of fruits $(\mathrm{cm})$, equilateral diameter of fruits $(\mathrm{cm})$, plant height at maturity stage $(\mathrm{cm})$, fruit weight $(\mathrm{g})$, number of fruits per plant, total soluble solids ( $\left({ }^{\circ}\right.$ Brix), ascorbic acid content $(\mathrm{mg} / 100 \mathrm{~g})$ and fruit yield per plant $(\mathrm{kg})$ were taken from 5 selected plants into consideration for estimating genetic diversity. The mean values of five plants were taken for the analysis of genetic divergence following Mahalanobis (1936). The genotypes were grouped into different clusters following Tocher's method as described by Rao (1952). The average intra and inter cluster distances and contribution of characters towards genetic divergence were estimated by using the method as described by Singh and Chaudhary (1977).

\section{Results and Discussion}

On the basis of $\mathrm{D}^{2}$ values, the 30 genotypes were grouped into six divergent clusters (Table 1 and Fig 1). Among the six clusters, cluster I was the largest, comprising of ten genotypes followed by cluster IV and cluster $\mathrm{V}$ with seven genotypes in each cluster, cluster II with four genotypes whereas cluster III and cluster VI consisted of one genotype each. The clustering pattern did not show any relationship between genetic diversity and geographic diversity. These results are in agreement with the early work of Shashikanth et al., (2010); Pedapati et al., (2014); Meena and Bahadur (2015); Dar et al., (2015). So, selection of genotypes for hybridization to generate diverse new gene combinations should be based on genetic diversity rather than geographic diversity.

The intra cluster distances indicates the divergence among the genotypes within the clusters and inter cluster indicates diversity between clusters. The intra and inter cluster $\mathrm{D}^{2}$ values among 30 genotypes (Table 2) revealed that maximum intra cluster $\mathrm{D}^{2}$ value was recorded in cluster V (550.48) whereas, cluster III and cluster VI showed minimum intra cluster $\mathrm{D}^{2}$ value $(0.00)$ followed by cluster IV (490.54) and cluster II (397.02) indicated that genotypes included in this cluster are very diverse and was due to both natural and artificial selection forces among the genotypes. Maximum inter cluster $\mathrm{D}^{2}$ value was observed between the cluster VI and III (7043.88) followed by cluster (5761.42), cluster IV and IV (4977.71), cluster VI and cluster I (4758.87), cluster VI and cluster II (4689.78) and Cluster IV and cluster III (2547.47) indicating that the genotypes belonging to these groups were genetically most divergent. These results are in accordance with the findings of Kumar et al., (2010); Meena and Bahadur (2013); Pedapati et al., (2014).

The means of the clusters for yield and quality traits (Table 3) depicted that plant height at maturity stage was minimum in cluster $\mathrm{V}(86.60 \mathrm{~cm})$ and maximum in cluster VI $(167.38 \mathrm{~cm})$. It indicates that if breeding aim is obtain dwarf (determinate) and long (indeterminate) plants, respectively. Then genotypes from these clusters would be selected. 
Table.1 Clustering pattern of 30 genotypes of tomato on the basis of $\mathrm{D}^{2}$ statistic

\begin{tabular}{|c|c|l|}
\hline $\begin{array}{c}\text { Cluster } \\
\text { No. }\end{array}$ & $\begin{array}{c}\text { No. of Ge notypes } \\
\text { within cluster }\end{array}$ & \\
\hline I & 10 & EC167860, Kashi Aman, EC177343, EC175957, Arka Saurabh, EC320574, RT 1, EC165952, Hawai, EC230571 \\
\hline II & 4 & EC251578, EC179038, Punjab upma, Hisar lalit \\
\hline III & 1 & EC235484 \\
\hline IV & 7 & EC177393, EC177516, Sawrna Kanchan, Hisar Anmol, Kashi Sharad, PKM-1, Arka Meghali \\
\hline V & 7 & EC257463, Palam Pink, EC257751, Punjab Chhuhara, Jawahar 99, Arka vikas, Kashi Amrit \\
\hline VI & 1 & EC257580 \\
\hline
\end{tabular}

Table.2 Mean intra and inter cluster distance $\left(D^{2}\right)$ among six clusters in tomato

\begin{tabular}{|c|c|c|c|c|c|c|}
\hline Cluster & Cluster I & Cluster II & Cluster III & Cluster IV & Cluster V & Cluster VI \\
\hline Cluster I & 379.42 & 596.75 & 1706.00 & 1079.02 & 997.01 & 4758.87 \\
\hline Cluster II & & 397.02 & 1776.63 & 871.26 & 1377.95 & 4689.79 \\
\hline Cluster III & & & 0.00 & 2547.48 & 1963.26 & 7043.88 \\
\hline Cluster IV & & & 490.54 & 1360.59 & 4977.71 \\
\hline Cluster V & & & & & 550.48 & 5761.42 \\
\hline Cluster VI & & & & & 0.00 \\
\hline
\end{tabular}


Table.3 Cluster mean for fifteen characters in tomato

\begin{tabular}{|c|c|c|c|c|c|c|c|c|c|c|c|c|c|c|c|}
\hline & PH & PB & $50 \% \mathrm{FL}$ & FL/C & $50 \% \mathrm{Fr}$ & Fr/C & Fr/P & Fr.W & Fr.PHM & PD & ED & Lo & TSS & $\mathbf{A A}$ & Y/P \\
\hline $\begin{array}{c}\text { Cluster } \\
\text { I }\end{array}$ & 103.663 & 10.620 & 54.617 & 6.883 & 63.555 & 3.653 & 36.889 & 29.622 & 90.293 & 2.127 & 2.367 & 4.099 & 4.557 & 25.958 & 1.032 \\
\hline $\begin{array}{c}\text { Cluster } \\
\text { II }\end{array}$ & 104.251 & 10.599 & 65.027 & 7.814 & 76.523 & 3.805 & 39.565 & 20.660 & 105.270 & 1.848 & 2.261 & 4.562 & 6.283 & 29.632 & 0.845 \\
\hline $\begin{array}{c}\text { Cluster } \\
\text { III }\end{array}$ & 94.257 & 8.377 & 55.357 & 6.533 & 62.490 & 3.163 & 26.693 & 41.937 & 87.550 & 0.980 & 3.297 & 9.000 & 5.890 & 24.023 & 1.130 \\
\hline $\begin{array}{c}\text { Cluster } \\
\text { IV }\end{array}$ & 95.942 & 9.864 & 56.673 & 6.935 & 65.926 & 3.215 & 29.370 & 40.516 & 94.807 & 2.813 & 2.506 & 3.736 & 5.358 & 36.119 & 1.179 \\
\hline $\begin{array}{c}\text { Cluster } \\
\text { V }\end{array}$ & 86.608 & 9.641 & 54.457 & 6.599 & 63.571 & 2.384 & 21.481 & 73.220 & 89.060 & 3.294 & 3.626 & 3.629 & 4.937 & 24.520 & 1.498 \\
\hline $\begin{array}{c}\text { Cluster } \\
\text { VI }\end{array}$ & 167.380 & 18.193 & 35.737 & 9.507 & 52.290 & 7.970 & 144.723 & 2.483 & 91.453 & 0.153 & 0.153 & 5.023 & 5.637 & 37.790 & 0.356 \\
\hline $\begin{array}{l}\mathrm{PH} \\
\mathrm{PB} \\
50 \% \mathrm{FL} \\
\text { FL/C } \\
50 \% \mathrm{Fr} \\
\text { Fr/C } \\
\text { Fr/P } \\
\text { Fr.W }\end{array}$ & $\begin{array}{l}=\text { Plant } \\
=\text { numb } \\
=\text { numb } \\
=\text { numb } \\
=\text { numb } \\
=\text { numb } \\
=\text { numb } \\
=\text { avera }\end{array}$ & $\begin{array}{l}\text { Height a } \\
\text { er of pri } \\
\text { er of day } \\
\text { er of flo } \\
\text { er of day } \\
\text { er of fru } \\
\text { er of fru } \\
\text { ge fruit }\end{array}$ & $\begin{array}{l}\text { t maturity } \\
\text { mary bran } \\
\text { s to fifty } \\
\text { wers per c } \\
\text { s to fifty } \\
\text { its per clu } \\
\text { its per pla } \\
\text { weight (g) }\end{array}$ & $\begin{array}{l}(\mathrm{cm}) \\
\text { ches per } \\
\text { er cent } \mathrm{f} \\
\text { luster } \\
\text { er cent } \mathrm{f} \\
\text { ter }\end{array}$ & $\begin{array}{l}\text { plant } \\
\text { flower in } \\
\text { fruit initi }\end{array}$ & $\begin{array}{l}\text { tiation } \\
\text { ation }\end{array}$ & $\begin{array}{l}\text { Fr.PH } \\
\text { PD } \\
\text { ED } \\
\text { Lo } \\
\text { TSS } \\
\text { AA } \\
\text { Y/P }\end{array}$ & $\begin{aligned} \mathrm{M} & = \\
& = \\
& = \\
& = \\
& = \\
& = \\
& =\end{aligned}$ & $\begin{array}{l}\text { Number } \\
\text { polar diar } \\
\text { equilatera } \\
\text { number o } \\
\text { total solu } \\
\text { ascorbic } \\
\text { fruit yielc }\end{array}$ & $\begin{array}{l}\text { f days } t \\
\text { neter of } \\
\text { l diame } \\
\text { f locule } \\
\text { ble solic } \\
\text { acid (me } \\
\text { per pla }\end{array}$ & $\begin{array}{l}\text { fruit } n \\
\text { fruit }(\mathrm{c} \\
\text { er of fr } \\
\text { per fru } \\
\mathrm{s}\left({ }^{0} \mathrm{~B}\right) \\
/ 100 \mathrm{~g}) \\
\mathrm{t}(\mathrm{kg})\end{array}$ & $\begin{array}{l}\text { naturity } \\
\mathrm{n}) \\
\text { ait }(\mathrm{cm})\end{array}$ & phy &. & age \\
\hline
\end{tabular}


Table.4 Contribution percentage of fifteen characters towards genetic divergence in tomato

\begin{tabular}{|c|c|c|c|}
\hline Sl. No. & Source & Times ranked 1st & Contribution \% \\
\hline 1 & Plant height at maturity $(\mathrm{cm})$ & 1.000 & 0.23 \\
\hline 2 & No. of primary branches/plant & 0.000 & 0.01 \\
\hline 3 & No. of Days to $50 \%$ f lower initiation & 3.000 & 0.69 \\
\hline 4 & No. of flowers per cluster & 0.000 & 0.01 \\
\hline 5 & No. of Days to $50 \%$ fruit initiation & 7.000 & 1.61 \\
\hline 6 & No. of Fruits per cluster & 4.000 & 0.92 \\
\hline 7 & No. of fruits per plant & 0.000 & 0.01 \\
\hline 8 & Average fruit weight (g) & 101.000 & 23.22 \\
\hline 9 & No. of days to physiological maturity & 4.000 & 0.92 \\
\hline 10 & Polar Diametre (cm) & 23.000 & 5.29 \\
\hline 11 & Equilateral Diametre $(\mathrm{cm})$ & 12.000 & 2.76 \\
\hline 12 & No. of locules per fruit & 50.000 & 11.49 \\
\hline 13 & Total Soluble Solid (\%) & 34.000 & 7.82 \\
\hline 14 & Ascorbic Acid content (mg/100g) & 167.000 & 38.39 \\
\hline 15 & Fruit yield per plant (kg) & 29.000 & 6.67 \\
\hline
\end{tabular}


Fig.1 Clustering pattern of 30 genotypes of tomato based of $D^{2}$ statistic by Tocher's method

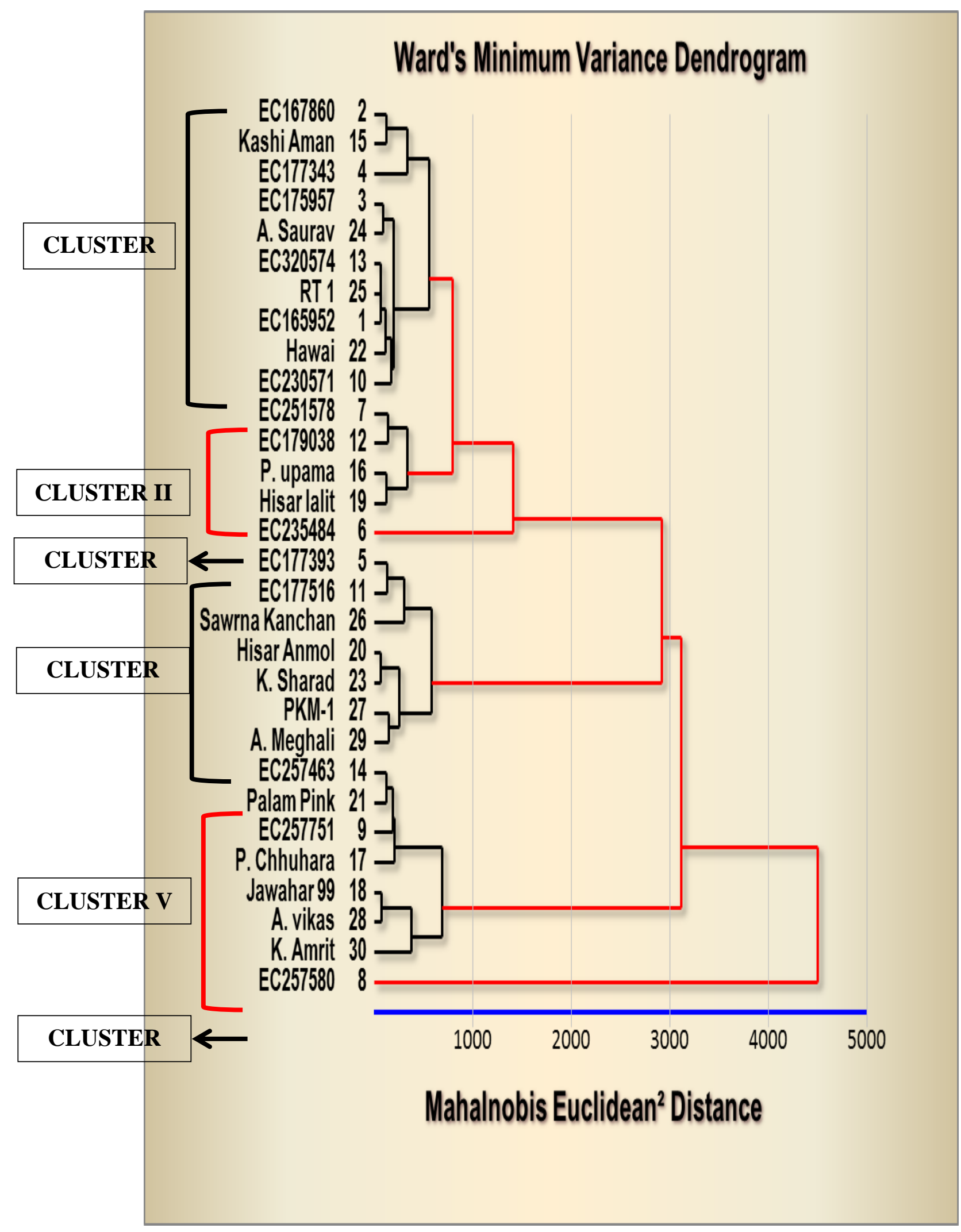


Maximum number of primary branches per plant was observed in cluster VI (18.19). It reveals that if breeding program is aimed to obtain maximum number of primary branches, then genotypes in these clusters can be selected. Number of days to $50 \%$ flower initiation was minimum in cluster VI (35.73 days), minimum number of days to $50 \%$ fruit initiation was observed in cluster VI (52.29 days), and minimum number of days to fruit maturity at physiological stage was found in cluster III (87.55 days). It reveals that if breeding program is aimed at earliness, then genotypes in these clusters can be selected. (Meena and Bahadur, 2013). Maximum number of flowers per cluster, maximum number of fruits per cluster and maximum number of fruits per plant were observed in cluster VI with 9.50, 7.97 and 144.72, respectively. Polar diametre of fruits and equilateral diameter of fruits were maximum in cluster $\mathrm{V}, 3.29 \mathrm{~cm}$ and $3.62 \mathrm{~cm}$, respectively. Average fruit weight was observed maximum in cluster $\mathrm{V}(73.22 \mathrm{~g})$. It was observed that clusters $\mathrm{V}$ highest values of $1.49 \mathrm{~kg}$ for fruit yield per plant. Which indicates that the accessions included in these clusters could effectively be used for the crop improvement program for increasing yield (Meena and Bahadur, 2015). Clusters V (3.62) had the minimum cluster mean value for number of locules. For total soluble solids, the highest values were observed in clusters II (6.28). However, clusters number VI (37.79mg) had highest values for ascorbic acid content. It indicates that the genotypes including these cluster could effectively used for the improvement for fruit quality.

Thus, from the present investigation it can be concluded that for earliness, genotype in cluster VI can be selected for development of double cross hybrids. To improve maximum yield per plant, clusters V and VI are an ideal combination for crossing or their derivatives for future selection.
The percentage contribution of 15 traits for genetic divergence (Table 4) showed that ascorbic acid content contributed maximum $(38.39 \%)$ towards genetic divergence followed by average fruit weight $(23.22 \%)$, number of locules per fruit $(11.49 \%)$, total soluble solids $(7.82 \%)$, fruit yield per plant $(6.67 \%)$ and polar diameter of fruit $(5.29 \%)$. Reddy et al., (2013) also observed such maximum contribution for plant height to total divergence of tomato accessions. Whereas, number of days to fifty percent fruit initiation (1.61\%), number of fruits per cluster $(0.92 \%)$, number of days to fifty percent flower initiation $(0.69 \%)$ and plant height at maturity stage $(0.23 \%)$. contributed minimally towards total divergence. However, number of primary branches per plant $(0.01 \%)$ and number of fruits per plant $(0.01 \%)$ contributed very less (negligible). Similar findings were obtained by early workers namely Dar et al., (2015) and Sekhar et al., (2008).

\section{References}

Singh, P.K. and Chaudhary, R.D. (1977). Biometrical methods in quantitative genetic analysis, Kalyani Publishers, New Delhi. 178-185.

Dar, R. A., Sharma, J.P. and Ahmad, M. (2015). Genetic diversity among some productive genotypes of tomato (Lycopersicon esculentum Mill.). African Journal of Biotechnology, 14(22): 1846-1853.

Kumar, S., Rattan, P, Sharma, J.P. and Gupta, R.K. (2010). $\mathrm{D}^{2}$ analysis for fruit yield and quality components in tomato (Lycopersicum esculentum Mill.). Indian Journal of Plant Genetic Resource, 23(3): 318-320.

Mahalanobis, P.C. (1936). On the generalized distance in statistics. Proc. Nat. Inst. Sci. India. 2: 49-55.

Meena, O. P. and Bahadur, V. (2015). 
Breeding potential of indeterminate tomato (Solanum lycopersicum 1.) accessions using $\mathrm{D}^{2}$ analysis. SABRAO J. breeding and genetics. 47(1): 49-59.

Omprakash Meena and Vijay Bahadur. (2013). Assessment of breeding potential of tomato (Lycopersicon esculentum Mill.) germplasm using $\mathrm{D}^{2}$ analysis. The Bioscan. 8(4): 1145-1148.

Pedapati, A., Reddy, R.V.S.K., Babu, D.J., Kumar, S.S. and Sunil, N. (2014). Genetic diversity analysis in Tomato (Solanum lycopersicum L.) Electronic Journal of Plant Breeding, 5(3): 517525.

Rao, C.R. (1952). Advanced statistical methods in Biometrics Research. John Wiley and Sons, New York. 357-369.

Rathi, S., Kumar, R., Munshi, A.D. and Verma, M. (2011). Breeding potential of brinjal genotypes using D2 analysis. Indian J. Hort. 68(3):328-331.

Reddy B.R., Reddy D.S., Reddaiah K., Sunil N. (2013). Studies on genetic variability, heritability and genetic advance for yield and quality traits in Tomato (Solanum lycopersicum L.). Int. J Curr. Microbiol. Appl. Sci. 2(9): 238244.

Reddy, B.R., Reddy, M.P., Begum, H.D. and Sunil, N. (2013). Genetic diversity studies in tomato(Solanum lycopersicum L.). IOSR Journal of Agriculture and Veterinary Science, 4(4): 53-55

Sekhar, L., Prakash, B.G., Salimath, P.M., Sridevi, O. and Patil, A.A. (2008). Genetic diversity among some productive hybrids of tomato (Lycopersicon esculentum Mill.). Karnataka J. Agric. Sci. 21(2): 264-265. Shashikanth, N., Basavaraj, B.C., Patil, P. M., Salimath, R.M., Hosamani, P.U. and Krishnaraj. (2010).Genetic Divergence in Tomato (Solanum Lysopersicon L). Karnataka Journal of Agriculture Science, 23 (3): 538-539.

\section{How to cite this article:}

Sooraj Maurya, A.K. Singh, S.K. Singh and Om Prakash Kumawat. 2019. Study of Genetic Divergence in Tomato (Solanum lycopersicum L.). Int.J.Curr.Microbiol.App.Sci. 8(08): 24292436. doi: https://doi.org/10.20546/ijcmas.2019.808.282 